Original Research Paper

\title{
Sosialisasi Program Kartu Tani Bagi Kios Tani Pengecer Pupuk Bersubsididan Kelompok Tani di Kecamatan Gangga Kabupaten Lombok Utara
}

\author{
Suprianto $^{1 *}$, Putu Karismawan ${ }^{1}$, Lukman Hakim ${ }^{1}$, Sujadi $^{1}$, Eka Agustiani $^{1}$ \\ ${ }^{\text {I}}$ Fakultas Ekonomi Bisnis, Universitas Mataram, Mataram, Indonesia
}

https://doi.org/10.29303/jpmpi.v3i2.1253

Sitasi: Suprianto., Karisamawan, P., Hakim, L., Sujadi \& Agustiani, E. (2021). Sosialisasi Program Kartu Tani Bagi Kios Tani Pengecer Pupuk Bersubsididan Kelompok Tani di Kecamatan Gangga Kabupaten Lombok Utara. Jurnal Pengabdian Magister Pendidikan IPA 4(4)

\section{Article history}

Received: 1 Oktober 2021

Revised: 30 Oktober 2021

Accepted: 30 November 2021

*Corresponding Author:

Suprianto, Fakultas Ekonomi Bisnis, Universitas Mataram, Mataram, Indonesia; Email: muliarta1@yahoo.co.id
Abstract: Kartu Tani adalah Kartu debit BNI co-branding yang di gunakan secara khusus untuk membaca alokasi Pupuk Bersubsidi dan transaksi Pembayaran pupuk Bersubsisid di Mesin Elektronik Data Capture (EDC) BNI yang ditempatkan di Pengecer serta dapat berfungsi untuk melakukan seluruh transaksi perbankan pada umumnya. Maksud Kartu Tani adalah Terwujudnya pendistribusian pengenadalian dan pengawasan pupuk bersubsidi kepada para petani yang berhak menerima. Tujuan terwujudnya distribusi pupuk bersubsidi sesuai dengan Asas 6 (enam) Tepat (Jumlah, Jenis, Waktu, Tempat, Mutu, dan Harga) serta pemberian layanan perbankan bagi petani. Kegiatan pengabdian tentang Sosialisasi Program Kartu Tani bagi Kios Tani Pengecer pupuk bersubsidi dan Kelompok Tani di Kecamatan GanggaKabupaten Lombok Utara dilaksanakan tanggal 3-4 Oktober 2021 bertempat di Kios Pengecer P3 Pelopor Kecamatan Gangga dengan peserta sebanyak 23 orang 20 orang petani, 1 pemiulik kios dan 2 orang dari perwakilan distributor pupuk bersubsidi CV. Sasak Agrotani. Sasaran adalah: 1. Petani yang tergabung dalam kelompok tani dan telah diusulkan untuk memperoleh pupuk bersubsidi melalui Rencana Devinitif Kebutuhan Kelompok (RDKK) yang telah disyahkan oleh Kepala Desa/Lurah dan Penyuluh Pertanian Lapangan (PPL) 2. Mempunyai KTP / NIK 3. Mengusahakan lahan untuk kegiatan bertani setiap musim tanam, petani yang melakukan usaha tani sub sector Tanaman Pangan, Perkebunan Hortikultura dan Peternakan. 4. Memiliki rekening tabungan di Bank BNI. Dari sasaran yang ada persyaratan tersebut telah dipenuhi oleh petani kelompok dan mereka telah memahami akan pentingnya memiliki kartu tani sebagai sarana dalam melakukan penbusan pupuk bersubsidi di kios pengecer yang telah ditunjuk moleh distributor pupuk. Kendala yang dihadapi dari peserta sebagian besar sudah melakukan pendaftran ke Bank BNI dan telah membuka rekening tabungan namun hingga saat ini mereka belum mendapatkan kartu tani, hal ini terkendala kebijakan dan koordinasi dinas terkait belum efektif dalam pengurusan penerbitan kartu tani untuk di wilaayah Kabupaten Lombok Utara pada umumnya.

Keywords: Kartu Tani, kios pengecer, pupuk bersubsidi 


\section{Pendahuluan}

Pembangunan pertanian dilakukan dengan memanfaatkan teknologi modern yang tepatguna dan berkelanjutan. Kegiatan pertanian di dominasi oleh penggunaan pupuk yang bertujuan untuk menghasilkan kualitas dan kuantitas dari hasil pertanian. Realitas yang seringkali ditemui oleh petani adalah kelangkaan pupuk, harga yang naikturun, ketika mendistribusikan pupuk untuk masyarakat mengalami masalah. Di dalam mengatasi kelangkaan pupuk yang terjadi, pemerintah menetapkan kebijakan yakni PeraturanPresiden No 7 Tahun 2005 tentang Rencana Pembangunan Jangka Menengah Nasional yang berfungsi sebagai bentuk pengawasan yang dilakukan pemerintah dalam mengawasi alokasi pupuk bersubsidi. Berdasarkan Petunjuk Pelaksanaan Penyediaan dan Penyaluran Pupuk Bersubsidi TA 2018 yang dikeluarkan oleh Kementerian Pertanian RI tahun 2017, pupuk bersubsidi adalah barang dalam pengawasan yang pengadaan dan penyalurannya mendapat subsidi dari Pemerintah untuk kebutuhan kelompok tani dan/ atau petani di sector pertanian.

Berdasarkan Juklak Penyediaan Pupuk Bersubsidi Tahun 2018 terdapat lima jenis pupuk bersubsidi yang dialokasikan untuk masyarakat yaitu urea, sp 36, za, npk, danorganik. Pemerintah Kabupatren Lombok Utara provinsi Nusa Tenggara Barat bekerjasama dengan Bank Negara Indonesia (BNI), menghadirkan kartu tani sebagai sarana dalam mengoptimalkan kebijakan pupuk bersubsidi bagi masyarakat. Kartu Tani Melalui Aplikasi Sistem Informasi Manajemen Pangan Indonesia di Provinsi Nusa Tenggara Barat telah diuji coba di kavupaten Sumbaua, merupakankartu debit BNI cobranding yang digunakan secara khusus untuk membaca alokasi pupuk bersubsidi dan transaksi pembayaran pupuk bersubsidi di mesin EDC (Electronic Data Capture) BNI yang ditempatkan di pengecer serta dapat berfungsi untuk melakukan seluruh transaksi perbankan pada umumnya.

Penggunaan kartutani terintegrasi dengan Aplikasi Sistem Informasi Manajemen Pangan Indonesia (SIMPI). Sistem tersebut berisikan data RDKK (Rencana Defiinitif Kebutuhan Kelompok) yang terdiri dari nama petani, luas lahan, jenis tanaman, dan alokasi pupuk yang dibutuhkan petani Tujuan dari program Kartutani bagi masyarakat adalah penyaluran pupuk bersubsidi yang tepat sasaran dengan berlandaskan pada enam asas yaitu Tepat jenis, Tepat jumlah, Tepat mutu, Tepat lokasi, Tepat waktu, Tepat harga. Petani yang menggunakan kartu tani mendapatkan pupuk bersubsidi sesuai kebutuhan diseluruh agen atau kios yang telah ditentukan, dimana kegiatan pertanian dapat berjalan aman tanpa terganggu oleh tidak tersedianya pupuk bersubsidi.

Kartu tani juga berfungsi sebagai tabungan yang dapat digunakan petani untuk memenuhi kebutuhan hidupnya.

Pemerintah melakukan suatu upaya pendistribusian pupuk bersubsidi mellui kartu tani yng bertujuan untuk meuujudkan pendistribusian secara mert serta pengendalian pupuk bersubsidi kepda petni yang berhak mendapatkan, akan tetpi belum semua petani mengapliksikan kartu tani dengan berbagai argumen kendala yangf dihadpi. (Devi Nurulfahmi ; 2019 ).

Pelaksanaan kartu tani yang dilakukan di Kecamatan Gangga Kabupaten Lombok Utara masih mengalami permasalahan dan belum dilaksanakan yakni dikarenakan keengganan masyarakat untuk menabung di bank BNI sehingga saldo yang ada di tabungan masih nol. Program kartu tani yang dilaksanakan di Kecamatan Gangga diharapkan tepat sasaran dalam mewujudkan pendistribusian pupuk bersubsidi dan pemanfaatan layanan perbankan bagi para petani. Dengan demikian dapat dilakukan pengabdian kepaada masyarakat untuk melakukan penyuluhan tentang Sosialisasi Program Kartu Tani kepada Distributor dan Kios Pengecer Pupuk Bersubsidi Di Kecamatan Gangga Kabupaten Lombok Utara. Program kartutani di Kecamatan Gangga Kabupaten Lombok Utara baru akan dilaksanakan pada tahun 2021 untuk mengetahui sejauh mana kesiapan kios pengecer pupuk bersubsidi maka perlu dilakukan penyuluhan sosialisasi program Kartutani.

Kartu Tani adalah Kartu debit BNI co-branding yang di gunakan secara khusus untuk membaca alokasi Pupuk Bersubsidi dan transaksi Pembayaran pupuk Bersubsisid di Mesin Elektronik Data Capture (EDC) BRI yang ditempatkan di Pengecer serta dapat berfungs iuntuk melakukan seluruh transaksi perbankan pada umumnya. Kartu tani sebagai sarana pemberian layanan perbankan yang lebih lengkap bagi para petni, termasuk untuk menabung dn mendptkn pinjaman Kredit Usaha Rakyat (KUR) Budidaya Pertanin (Media9 ; 2020). Maksud KartuTani adalah Terwujudnya 
pendistribusian pengenadalian dan pengawasan pupuk bersubsidi kepada para petani yang berhak menerima Terwujudnya distribusi pupuk bersubsidi sesuai dengan Asas 6 (enam) Tepat (Jumlah, Jenis, Waktu, Tempat, Mutu, dan Harga) serta pemberian layanan perbankan bagi petani. Permasalahan umum yang dihadapi oleh kios pengecer pupuk bersubsidi dan petani pada saat penebusan atau pembelian pupuk adalah sebagai berikut : a. Petani dan kios pengecer pupuk belum memahami program Kartu Tani. b. Pengetahuan petani dan kios pengecer terbatas untuk menjalankan transaksi elektronik dengan e-Kartu Tani. c. Kendalanya pada saat pembelian pupuk bersubsidi petani dan kios tani harus mengisi saldo di rekening BNI. d. Banyak petani yang tidak sesuai NIK dan Kartu Keluarga di alokasi e-RDKK. e. Ketersediaan pupuk bersubsidi sering terlambat sehingga petani beralih menggunakan pupuk lain atau pupuk non subsidi.

\section{Metode}

Metode yang digunakan dlam pelaksanaan penyuluhan dan pelatihan sosialisasi program kartu tani di kecamatan Gangga Kabupaten Lombok Utara adalah sebagai berikut :

1. Ceramah penyampaian materi yang diberikan oleh tim pengabdian, pihak Bank BNI dan Kepala dinas atau pejabat yang meakili dari Dinas Pertanian Kabupaten Lombok Utara.

2. Tanya jawab /diskusi

3. Pada akhir penyuluhan dan pelatihan pengisian data penebusan pupuk bersubsidi, peserta dibagikan buku tabungan dan petunjuk teknis dalam pengisian data elektronik.

4. Akhir penyuluhan ada umpan balik tentang, pengetahuan peserta setelah mengikuti penyuluhan.

a. Materi penyuluhan yang disampaikan,

b. Sistem dan metode yang digunakan .

c. Saran dan masukan untuk tim pelaksana

Penentuan petani yang dapat memiliki kartu tani dalam melakukan transaksi pembelian pupuk di kios pengecer adalah sebagai berikut :

1. Petani telah terdaftar pada kelompok tani di uilayah hamparan sauahnya

2. Nama petani sesuai dengan NIK dan Kartu keluarga yang terdaftar di e-RDKK
3. Kelompok Tani melalui ketua kelompok meneruskan ke kios pengecer dan Distributor pupuk bersubsidi.

\section{Hasil dan Pembahasan}

\section{Pelaksanan Kegiatan}

Kegiatan Pengabdian Kepada Masyarakat berupa Sosialisasi Program Kartu Tani Bagi Kios Tani Pengecer Pupuk Bersubsidi dan Kelompok Tani Di Kecamatan Gangga Kabupaten Lombok Utara dilaksanakan selama satu minggu, yaitu dimulai dari persiapan, mendata anggota kelompok tani sebagai peserta, persiapan lokasi dan tempat pelaksanaan penyuluhan, persiapan peralatan dan akomodasi , hari ke lima dan enam pelaksanaan penyuluhan. Kegiatan pengabdian kepada masyarakat ini dilaksanakan pada tanggal $9-10$ Oktober 2021 bertempat di aula Kios Pengecer P3 Pelopor di desa Gannga Kecamatan Gangga kabupaten Lombok Utara. Peserta yang hadir padaa saat kegiatan sosialisasi program kartu tani berjumlah 21 orang pada hari pertama dan 23 orang pada pelaksanaan hari ke dua dan dihadiri oleh perwakilan distributor pupuk bersubsidi CV. Sasak Agrotani, Kios Pengecer dan anggota kelompok tani serta 3 (tiga) orang mahasiswa yang berdomisili di Tanjung dan Gangga.

Pelaksanaan kegiatan sosialisasi program kartu tani dibagi ke dalam 2 (dua) tahap yaitu penyajian materi dan simulasi tanya jawab melalui diskusi. Materi penyuluhan sosialisasi program kartu tani dilakukan dengan ceramah berupa pengetahuan informasi tentang:

1. Pengenalan Program Kartu Tani

2. Apa itu kartu tani

3. Manfaat kartu tani bagi petani

4. Sosialisasi penggunaan Kartu Tani

5. Syarat untuk memiliki kartu tani

Media yang digunakan dalam kegiatan penyuluhan ini adalah laptop, LCD dan wireless serta materi penyuluhan yang dibagikan kepada peserta. Pada saat pelaksanaan penyampaian materi berakhir para peserta penyuluhan diberikan waktu kesempatan untuk diskusi dan tanya jawab permasalahan yang dihadapi oleh peserta dan setelah berakhirnya session tanya jawab anggota tim menyebarkan angket isian sebagai bahan evaluasi terhadap pengetahuan peserta dalam kegiatan penyuluhan ini. 
Kegiatan berikutnya adalah mereviu permasalahan yang dihadapi oleh peserta penyuluhan berkaitan dengan tatacara penebusan pupuk bersubsidi produksi PT. Petro Kimia Gersik yang ditangani oleh distributor CV. Sasak Agrotani terkait dengan penyaluran pupuk bersubsidi kepada anggota kelompok tani yang penebusannya ditangani oleh Kios pengecer P3 Pelopor. Pertanyaan dari para peserta berkaitan dengan :

1. Penyaluran pupuk bersubsidi di kecamatan Gangga Kabupaten Lombok Utara

2. Terkait dengan program kartu tani dimana 14 kelompok tani di desa gondang sudah membuka rekening di bank BNI unit Tanjung.

3. Kartu tani belum berlaku di kecamatan Gangga

4. Kebutuhan pupuk ke petani semakin tinggi sementara harga pupuk non subsidi harganya semakin tinggi.

5. Perubahan dosis penggunaan pupuk untuk urea antara $125 \mathrm{Kg}$ smpai dengan $150 \mathrm{~kg}$ per Ha lahan ditambah NPK plus $200-300 \mathrm{~kg}$

\section{Hasil Kegiatan}

Selama berlangsungnya penyuluhan sosialisasi program kartu tani bagi petani dan kelompok tani dapat ditarik kesimpulan sebagai berikut:

1. Para peserta Sebagian besar sudah pernah mendengar program kartu tani yang diluncurkan oleh pemerintah.dan setealah mengikuti penyuluihan dan sosialisasi program mkartu tani mereka memahami akan pentingnya memiliki kartu tani untuk kelancaran penebusan pupuk bersubsidi.

2. Penguasaan kartu tani Sebagian besar peserta belum terdaftar untuk mendapatkan kartu tani karena diwajibkan untuk membuka tabungan di Bank BNI, sehingga secara praktik mereka belum dapat mengoperasikan kartun tani tersebut.

3. Pendaftaran bagi peserta dari diskusi sudah ada yang mendaptar sebanyak 14 kelompok dan sudah membuka rekening di bank BNI, namun masih belum di proses permohonannya untuk mendapatkan kartu tani.

4. Sebagian peserta dari kelompok tani yang ada dan telah mendaftar diberikan buku rekening langsung oleh Bank BNI unit Tanjung sebagai bank pemerintah yang menangani kartu tani di wilayah Lombok Utara.
5. Sedianya kartu tani itu fungsinya sama seperti ATM dapat digunakan untuk transaksi pembelian pupuk dan transaksi keuangan lainnya seperti ATM pada umumnya.

Sebagai tindak lanjut dari hasil penyuluhan tentang sosialisasi program kartu tani bagi kios tani pengecer pupuk bersubsidi dan kelompok tani di kecamatan Gangga kabupaten Lombok Utara adalah :

1. Hendaknya pemda kabupaten Lombok Utara segera menindak lanjuti program kartu tani ini melalui dinas-dinas terkait yaitu dinas pertanian, dan dinas perdagangan serta Bank BNI unit Tanjung

2. Petani kelompok yang telah mendaftar dan membuka tabungan segera dapat diterbitkan kartu taninya agar dapat dimanfaatkan untuk penebusan pupuk bersubsidi.

3. Dengan berkurangnya alokasi pupuk bersubsidi petani terpaksa membeli pupuk non subsidi dengan harga yang tinggi untuk memenuhi kebutuhan tanaman padinya.

4. Secara umum kartu tani belum berlaku di wilayah tanjong dan gangga serta kecamatan lainnya sehingga petani dalam penebusan pupuk bersubsidi masih secara manual melalui pemesanan kelompok ke kios tani pengecer.

5. Dengan kebutuhan pupuk bersubsidi yang semakin tinggi pemerintah hendaknya menambah alokasi pupuk di kecamatan Gangga.

Di dalam mencapai tujuan program kartu tani secara menyeluruh terdapat tahapan-tahapan pelaksanaan program kartu tani yang dilaksanakan di Kios Pengecer Pupuk Bersubsidi P3 PELOPOR Kecamatan Gangga Kabupaten Lombok Utara:

Sosialisasi Program Kartu Tani, bertujuan untuk memberikan informasi terkait dengan gambaran umum program beserta tata cara program. Informasi yang disampaikan dalam sosialisasi diharapkan dapat tersampaikan dengan baik sehingga anggota kelompok tani mampu menerima dan melaksanakan program yang ditentukan sebelumya. Sosialisasi program kartu tani di kecamatan Gangga dilaksanakan 2 hari di Kios Tani P3 Pelopor pada tanggal 3 dan 4 Oktober 2021 dihadiri oleh 23 petani peserta anggota kelompok tani , ketua kelompok tani, dan pemilik kios P3 Pelopor, PPL, dan 2 (dua) mahasiswa pendamping dan Distributor CV. Sasak Agrotani 
penyalur pupuk bersubsidi Petrokimia Gersik yang merupakan wilayah kerja dari pendistribusian pupuk bersubsidi untuk kelompok Tani yang berada di kecamatan Gangga Kabupaten Lombok Utara. Pihak yang berperan dalam menyampaikan informasi adalah pegawai BPP yang merupakan penyuluh tingkat kecamatan. Sosialisasi tersebut dilakukan pada tahun 2021 dan bertempat di Balai Pertemuan Kios Pengecer P3Pelopor di Kecamatan Gangga Kabupaten Lombok Utara. Kegiatan awal dilakukan pendataan peserta yang diambil secara acak dari beberapa kelompok tani dengan peserta sebanyak 23 orang petani. Keberadaan penyuluh di setiap wilayah binaan berperan penting dalam proses pendataan karena setiap penyuluh akan melakukan pertemuan yang telah dijadwal sebelumnya dan akan mendata per kelompok sebelum nantinya dimasukkan atau di entry pada sistem oleh admin. Proses pendataan selain mendata nama pemilik atau petani, juga mewajibkan anggota kelompok tani untuk mengumpulkan berkas persyaratan seperti fotocopy KTP, kartu keluarga. BPP Kecamatan Gangga lebih berperan sebagai pihak yang membantu atau mendampingi terselarangganya kegiatan pengurusan kartu tani di karenakan petani memang lebih dekat penyuluh. Jika petani yang bersangkutan tidak datang maka akan dilakukan pengarahan dan pemberitahuan untuk bersamna sama kelompoknya mendaftarkan dirinya ke Bank BNI yang menangani penerbitan kartu tani untuk wilayah kecamatan Gangga. Dari peserta yang hadir sebagian ada yang telah mendaftar atau sebanyak 27 anggota petani kelompok tani telah mendaftarkan diri ke Bank BNI untuk mendapatakan kartu tani , namun sampai sekarang pihak bank dan instansi terkait yang menangani kartu tani belum dapat mengeluarkan kartu tani di wilayah kecamatan Gangga. Penggunaan Kartu tani yang akan dibagikan ini pada petani dapat dimanfaatkan dalam kegiatan transaksi pembelian pupuk, selain itu juga berfungsi sebagai alat untuk transaksi kebutuhan sehari-hari. Pembelian pupuk bersubsidi dengan kartu tani dapat dilakukan pada kios kios yang telah ditunjuk secara resmi oleh pemerintah dengan menunjukkan kartu tani yang dimiliki kemudian penjual akan menggesek di mesin EDC, jika terdapat kecocokan dalam data alokasi pupuk dengan mesin EDC maka terjadilah transaksi jual beli pupuk.
Kendala yang dihadapi oleh peserta penyuluhan dalam pengurusan kartu tani bahwa mereka diwajibakan membuka rekening tabungan di Bank BNI setempat dengan menyetorkan sejumlah uang minimal Rp 100.000 sampai dengan Rp 200.000 rupiah dan mengisi saldo untuk dapat digunakan dalam penebusan pupuk bersubsidi di kios tani yang telah ditunjuk sesuai dengan petunjuk dalam RDKK. Saldo yang mengendap di rekening BNI ini sejumlah nilai pupuk yang akan di tebus di kios pengecer, ini yang menjadi kendala dalam penyetotoran saldo awal dalam penebusan pupuk bersubsidi, mkarena belum tentu semua petani memiliki dana atau siap dana untuk disetorkan ke bank BNI setempat.

\section{Kesimpulan}

Kegiatan pengabdian berupa penyuluhan tentang Sosialisasi Program Kartu Tani bagi Kios Tani Pengecer Pupuk Bersubsidi Dan Kelompok Tani Di Kecamatan Gangga Kabupaten Lombok Utara berjalan sesuai dengan yang direncanakan. Awal dari kegitan melakukan test pengetahuan tentang program kartu tani, selanjutnya dilakukan penyampaian materi dari tim pengabdian selama 30 menit kemudian dilanjutkan dengan diskusi . Pada umumnya petani kelompok dapat memahami program kartu tani dan mereka sangat antusias ingin memiliki kartu tani, namun hingga saat ini program kartu tani di wilayah kecamatan Gangga masih belum terlaksana. Dari sebagian peserta dan petani (27 orang petani) lainnya sudah mendaftarkan ke Bank BNI untuk proses administrasi dengan membuka rekening tabungan BNI, namun hingga saat permohonan mereka belum diproses. Kendala yang dihadapi oleh petani lainnya dalam pengurusan kartu tani mereka terkendala dengan setoran pada pembukaan rekening awal yang diharuskan untuk mengisi saldo pada rekening mereka.

\section{Ucapan Terimakasih}

Ucapan terima kasih di sampaikan kepada Universitas Mataram yang telah membiayai program Pengabdian Kepada Masyarakat Sumber Dana dipa BLU (PNPB) 2021. 


\section{Daftar Pustaka}

........... Buku Petunjuk e-Banking penggunaanKartu Tani (2020). Peraturan Mentri Pertanian N0. 10 Tahun 2020 Tentang Alokasi dan HET Tertinggi Pupuk Bersubsidi Sektor Pertanian.

(2020). Peraturan Mentan Nomor 49 Tahun 2020 Tentang Pupuk BERSUBSIDI , (2020). Manfaat Petani memiliki Kartu Tani. Kompas. Com Agustus 2019

Media ( (2020). BNI Hadirkan Kartu Tani Untuk meningkatkan Produktivitas Petani. 13 Juli 2020

Sukartaui (2004). Pemasaran Pertanian. Penerbit Ghalia Indonesia

Devi Nurul Fahmi. Maria. (2020). Persepsi Petani Terhadap Implementasi Kartu Tani (Studi Kasus Desa Kalirejo Kecamatan Pabelan Kabupaten Semarang). Jurnal Agrisep Vol 19 No. 2

Moko K U. S.B .U. U (2020). Persepsi Petani Terhadap Program Kartu Tani Di Kecamatan Kalijambe Kabupaten Sragen . Agriculture 32(1) - 9 